\title{
Exploring the opinions of pre-service science teachers in their experimental designs prepared based on various approaches
}

\author{
Elif Benzer ${ }^{1}$ \\ ${ }^{1}$ Department of Science Education, Marmara University, İstanbul, Turkey \\ For correspondence: epehlivanlar@gmail.com
}

\begin{abstract}
The students in working in laboratories in 21st century are preferred to take place as active participants in the experiments coming up with their own designs and projects by developing new ideas and problems rather than implementing the ones told and ordered by others during these experiments. The science teachers that would have the students undertake these roles would be needed to know and have experienced various experiment designs and projects. From this point of view, in this study; it is aimed to receive their opinions on experimental designs prepared based on 5E, scientific process skills and constructivist-approach. The pattern of the study happens to be a case study and the data is gathered by directing seven open-ended questions to the 42 teacher candidates on their three experiments. In the end, it was established that the teacher candidates have had opinions in favour of the experiment designs.
\end{abstract}

Keywords: Science education, science teacher candidates, experimental designs with various techniques.

\section{Introduction}

Since early 19th century, laboratory practices have become an indispensable part of science education (Hofstede, 2004) and has acquired a central role in science education today (Bates, 1978; Hofstein and Lunetta, 2004; Aydoğdu and Ergin, 2010; Dahar and Faize, 2011) . Laboratory practices provide concrete experiences for students to learn both the concepts of science and the scientific method (Yildız et al., 2006), support conceptual and epistemological learning (Bell, 2004), positively influence students' attitudes (Yeung et al., 2011), and build up an efficient background for the development of high-level cognitive skills such as critical thinking skills and problem-solving skills (Zoller and Pushkin, 2007).

Laboratory practices can be configured in different ways based on various learning conditions such as the subject addressed, resources of the school, the teacher's and the student's readiness, etc. In this respect, particularly driven by evolving technology today, science educators integrate distinct strategies, methods and approaches into laboratory practices and employ them as effectively as possible to achieve their goals.

Among science educators, the question "What can be done in science lab practices to ensure better student learning?" has been the constant object of interest on laboratory practices (Domin, 2007). This question has led to the development of various types of experiments and laboratory practices to achieve more successful learning outcomes. Experiment types and laboratory approaches referred to in various studies are as follows:

Çepni et al. (1997) argue that there are three types of experiments, namely close-ended, open-ended and hypothesis testing experiments: 
Table 1. Types of experiments according to Çepni et al. (1997)

\begin{tabular}{|c|c|c|c|}
\hline \multicolumn{2}{|c|}{ Close-ended experiments } & Open-ended experiments & Hypothesis testing experiments \\
\hline 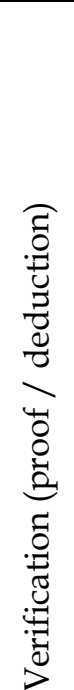 & $\begin{array}{l}\text { In this approach, } \\
\text { concept, principles and } \\
\text { laws or the subject are } \\
\text { presented through } \\
\text { various methods and } \\
\text { techniques (lecture, } \\
\text { discussion, question } \\
\text { and answer, or } \\
\text { reading, etc.). Then, } \\
\text { intended subjects are } \\
\text { proven by means of } \\
\text { concrete materials in } \\
\text { the laboratory. }\end{array}$ & 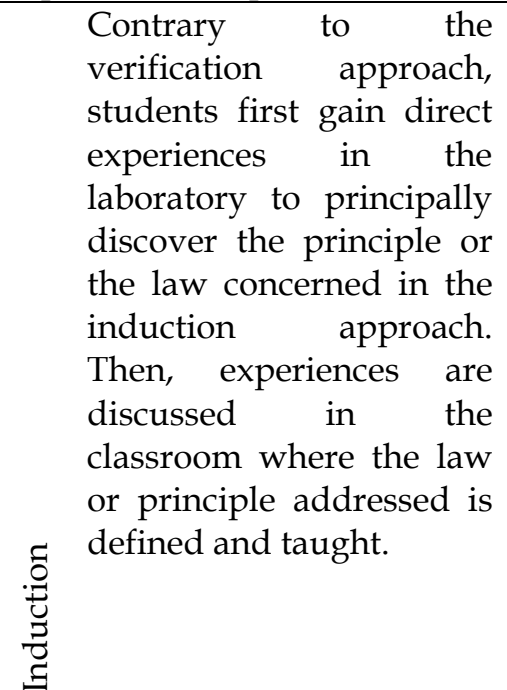 & 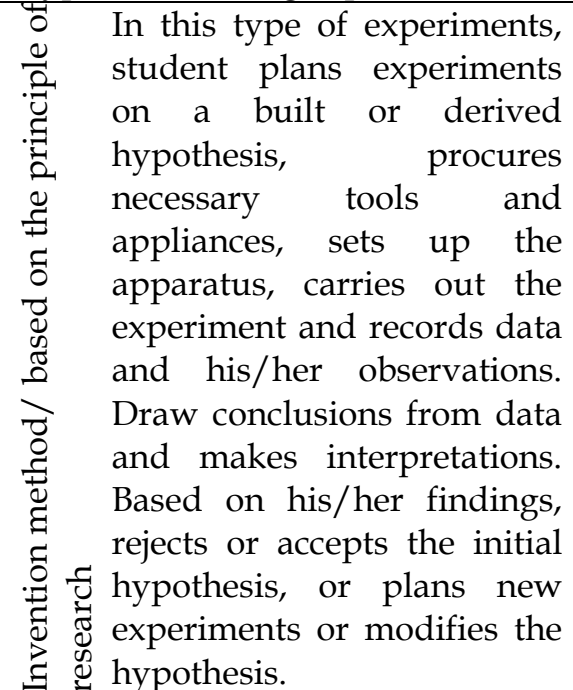 \\
\hline
\end{tabular}

Domin (1999) reports four different types of experiments based on anticipated laboratory results, students' approaches to experiments, and whether the experiment method is provided or not (cited by Mc Donnell et al., 2007):

Table 2. Types of experiments described by Domin (1999) (quoted by Mc Donnell et al., 2007).

\begin{tabular}{llll}
\hline Types of Experiments & Markers Result & Approach & Steps \\
\hline Descriptive & Predetermined & Deductive & Readily available \\
Query-based & Uncertain & Inductive & Student-made \\
Discovery-based & Predetermined & Inductive & Readily available \\
Problem-oriented & Predetermined & Deductive & Student-made \\
\hline
\end{tabular}

Schwab (1960) proposes three approaches based on whether students utilize manuals or materials in laboratory practices (quoted by NRC, 2000):

1. Laboratory manuals and materials allow students to ask, design a method to search for answers, and thus discover the relationships unknown to them.

2. Teaching materials may be employed to ask questions, however answers to these questions and method utilized to reach these answers should be left open for the students to identify them by themselves.

3. Without laboratory manuals or materials, students may, when confronted by some events, ask questions, collect evidence and derive scientific conclusions based on their own findings.

Berg (2009) describes three different laboratory types classified by the goals of laboratory practices, namely learning of the concept, learning of the process and use of tools-equipment. Each of these laboratory types requires the use of different approaches to teaching, learning and evaluation:

1. Concepts laboratories: Focusses on the removal of misconceptions and concept teaching.

2. Equipment laboratories: Focusses on the learning of basic application skills such as using microscope, preparing solutions.

3. Research laboratories: Focusses on the method of research. Applications aimed at developing skills necessary to produce and test information are performed.

Marbach-Ad and Claassen (2001) suggest four approaches to laboratory use. These are research-based laboratories, open-ended laboratories, query-based laboratories and induction laboratories. Each of these types differs from each other by resource (student or teacher) and nature of the problem originally for each type (open-ended, closed-ended). 
Laboratory practices have been explored in various studies in the literature in terms of teaching approaches, methodology and strategies. In these studies, designs were created based on the following approaches: 5E (Sevinç, 2008; Küçük, 2011; Erdoğdu, 2011); scientific process skills (Çakal, 2012); REACT (Ültay and Çalış, 2011; Demircioğlu et al., 2012); TGA (Karatekin and Öztürk, 2012; Bilen and Aydoğdu, 2010; Bilen and Aydoğdu, 2012; Özdemir, 2011; Bilen and Köse, 2012; Bilen et al., 2011); integrative laboratory model (Yeşilyurt et al., 2004) and constructivist approach (Ar1 and Bayram, 2011; Tümay, 2001). In addition, key impacts of some technology-assisted methods (simulation, web based, etc.) to achieve more gains compared to experiments were suggested (Bhukuvhani et al., 2010; Çetin and Günay, 2011; Bozkurt and Sarıkoç, 2008; Tütsüz, 2010; Hofstein and Lunetta, 2004; Şahin, 2006).

Predict-Observe-Explain (POE) is a three-stage application. This method provides students with opportunities for utilizing scientific process skills, and allows them to work as scientists, using scientific methods. As a learning approach allowing the students to build links with new learnings based on their previous background and providing a meaningful way of expressing them, this method is very suitable for the topics of science (Bilen, 2009). REACT strategy is composed of the steps of relating, experiencing, applying, cooperating and transferring (Ültay and Çalık, 2011). Crawford (2001) describes these steps as follows (quoted by Coştu, 2009): Relating involves learning by establishing a context with the person's prior knowledge and experience. Experiencing involves learning by doing or exploring, discovering and inventing. Applying involves learning by introducing the concepts to be used. Cooperating involves learning by sharing with and responding to others. Transferring involves using knowledge in a new context not mentioned in the class.

$5 \mathrm{E}$ is a model that allows students to take a more active role during the learning process. The phases of the 5E learning model are as follows (Patro, 2008): Engage: An introduction is made into the topic to excite the students. Explore: Students are provided with opportunities to explore an issue/problem. Explanation: Students provide a concluding explanation of their exploration. Elaborate: The topic is explored more exhaustively. Evaluate: Student's learning is evaluated throughout the process. Scientific process skills; are the skills employed by individuals understanding the nature of science, enhancing the quality of life and having scientific literacy (Aktamış and Ergin, 2008; Huppert and Lazarowitz, 2002). Regardless of the laboratory approach adopted, scientific process skills are the key skills necessary to achieve the purpose of the test application. Focussing on experiments, observations, research and exploration in classes flourishes these skills. And development of these skills is conducive to associating the experiments with the topic, and structuring the concepts in the mind (Tan and Temiz, 2003).

In a study by Aydoğdu and Ergin (2008:2010) where open-ended and research-based experiment methods were employed as different experimental techniques, the influences of different experimental techniques in the approaches of secondary school students to learning science (Aydoğdu and Ergin, 2010) and to scientific process skills (Aydoğdu and Ergin, 2008) in the 7th grade science and technology class were explored. Studies were conducted with two experiment groups and one control group during an eight-week period. Open-ended experiment method, research-based experiment method and experiments involved in the curriculum were applied in the first experiment group, second experiment group and the control group respectively. The study has revealed significant differences in favour of experiment groups in students' approach to learning science and in scientific process skills.

For the laboratory to achieve its intended goals in science education, key component is the science teacher along with all the above mentioned different approaches (Ylldiz et al., 2010). Pre-service science teachers should be trained towards gaining the skills and self-confidence of efficiently using the laboratory, and designing and implementing experiments besides professional knowledge and skills of science teaching, and teacher training programs should be reshaped accordingly (Kocakülah and Savaş, 2011). Capability of pre-service science teachers to identify different experiment designs, and their views are considered crucial as these would reflect the initial signs of using experiments during the formal service. In this regard, the study is aimed at exploring the opinion of third grade students of science teaching on different experiment designs they have experienced. The study was 
limited to the properties of the three approaches into which the experiments were integrated (experiment designs based on 5E learning model, scientific process skills and constructivist approach), and to the hazards of smoking, osmosis and topics selected from the elementary science and technology curriculum for grade 6, 7 and 8 (Ministry of Education (MEB), 2006). In the study, the problem statement was set as "What are the opinions of pre-service teachers in designing experiments through different methods?".

\section{Method}

In the study, opinions of teachers were determined through open-ended questions, therefore a qualitative method was adopted. Pre-service science teachers at grade 3 in a university of Istanbul during the 2011-2012 academic year constitute the study population. The study population consists of 42 pre-service teachers. Of them $4(10 \%)$ are male and $38(90 \%)$ are female. Since the study population was not selected as a purpose-based group where certain characteristics were considered for different experiment designs, randomization principle was used for construction.

Data Collection Tools. As the data collection tool, the "Form to Identify the Opinions of Pre-service Teachers in Experiment Designs" was used. In order to pick the opinions of pre-service teachers in the 5E learning model, scientific process skills and the constructivist approach, two questions for each experiment design were asked after the completion of that design (considering three experiment methods, six open-ended questions were asked to pre-service teachers.). In addition, after the last experiment conducted, students were asked to compare similarities and differences of using these three different approaches in the experiment design. To this end, pre-service teachers replied a total of seven open-ended questions. The purposes of asking open-ended questions in the study are as follows:

1. The purpose of the questions defining the experiment design was to explore the characteristics of the teaching method underlying each experiment, integrate these characteristics into laboratory practices, and identify student's role throughout the entire laboratory practice.

2. The purpose of the questions on the positive and negative aspects of experiment designs was to identify the opinions of teachers in the strengths and weaknesses of each design based on its specific characteristics.

3. The purpose of the questions stating similarities and differences of experiment designs was to identify the opinions of pre-service teachers in how experiment designs converge to and diverge from each other.

Before applying, open-ended questions were asked, as accompanied by the reasons for asking, to two faculty academicians involved in science education. Based on the opinions of faculty members, three open-ended questions found to be very similar or unclear were excluded from the questionnaire. Open-ended questions are presented in the table at the findings section. Next, in order to ensure the reliability of the study, experiment reports prepared by the students of previous terms were evaluated by different researchers, yielding a match rate of $84 \%$ for $5 \mathrm{E}$ ( 3 faculty members), $90 \%$ for scientific process skills ( 2 faculty members), and $82 \%$ for the constructivist approach (2 faculty members).

Analysing the data. Open-ended questions were used to identify the opinions of pre-service teachers in different experiment designs. Responses to open-ended questions were evaluated by content analysis through codes derived from the data. Code development by content analysis follows the following steps; 1) Data are collected, 2) A copy of the data is recorded in computer, 3) Data are reviewed to form an opinion, 4) Codes are derived from the data, 5) Themes are built and defined (Creswell, 2008).

Accordingly, responses of pre-service teachers were encoded and themes were built. Data were presented in a tabular form involving excerpts from pre-service teachers for each code, codes, and frequency of codes. In following segments of the tables, comments on data were provided, and an excerpt from the response of a pre-service teacher was presented for each experiment design in order 
to create a general framework. Excerpts of responses were condensed to particularly involve highlighted code statements; however sections cut were marked with "..." in an aim to demonstrate that the pre-service teacher's response is more extended.

On the other hand, in open-ended questions structured to pick the opinions of pre-service teachers in the similarities and distinctions of three different experiment designs, again content analysis was conducted, however clusters were formed to reshape similarities and distinctions in the intersection and union of such clusters. Later, excerpts of responses were provided to represent the opinions of pre-service teachers.

\section{Findings}

This section is composed of three headings. In this sub-problem, opinions of pre-service teachers in each experiment design were picked. Themes and codes developed across these opinions were tabulated by creating one row for each respondent, and presented as accompanied with excerpts of pre-service teachers' responses. In this section, findings were presented in three parts as structured by the open-ended questions. Here, pre-service teachers' opinions in the description, positive and negative aspects, and similarities and distinctions of experiment designs were provided in part one, two and three respectively.

Table 3. Findings on how pre-service teachers describe different experiment designs

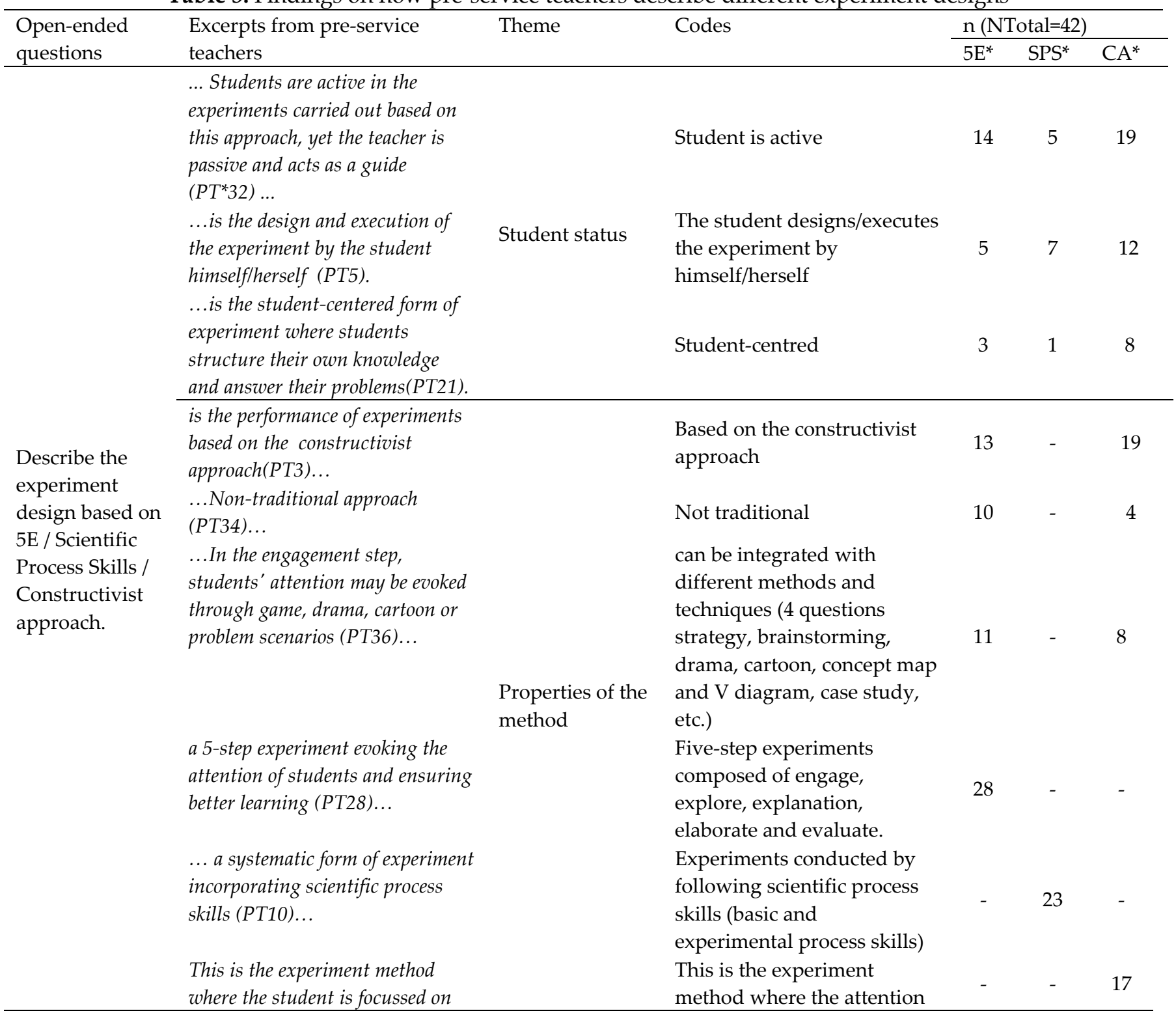



the topic, urged to think, build links with background knowledge and design the experiment based on the problem shaping in his/her
of student is initially evoked, then the experiment is designed accordingly, and finally evaluated. mind, and where the entire process is evaluated finally (PT13).

For the student to solve the problems encountered and overcome daily issues (PT20)...

... conducted to evoke the attention of students to drive better learning (PT28)...

... conducted to direct students to researching and carry out the experiment inquiringly (PT6)...
To solve the problem

$14 \quad 22$

10

To test learning

Objectives 2

To research

* 5E: experiments designed based on the 5E learning model, SPS: Experiments based on the Scientific Process Skills, CA: Experiments based on the constructivist approach, PT: Pre-service Teacher.

As shown in Table 3, pre-service teachers believe that students are active particularly in experiments based on 5E and the constructivist approach (5E:15, CA:19). In experiments set up based on the scientific process skills, relatively fewer answers were provided on the status of students during the experiment. The methodology of the experiment designs applied reveals that experiments based on $5 \mathrm{E}$ and constructivist approach are not traditional (5E:10, CA:4), are based on a constructivist approach (5E:13, CA:19), and can incorporate different methods and techniques (5E:11, CA:8). On the other hand, the formal characteristics of experiment designs have varied, revealing more frequent statement of certain responses based on decisive features of each experiment design (5E:28, SPS:23, CA:17). When expressing their opinions in each experiment design under these codes, pre-service teachers individually explain the formal characteristics (steps of the experiment design). It was further observed that pre-service teachers state the goal when describing different experiment designs. Accordingly, all three experiment designs are most commonly employed to solve a problem (5E:14, SPS:22, CA:10). Then, eliciting learning 5E:6, SPS:2, CA:8) and making research (5E:2, SPS:6, $\mathrm{CA}: 2)$ are aimed during the steps of this experiment design.

Here are excerpts from the responses of pre-service teachers:

Table 4. Excerpts from the responses of pre-service teachers on the description of different experiment designs

\begin{tabular}{l} 
5E SPS \\
In the "engage" step in 5E When called to carry out an In carrying out the experiment based \\
method, student's attention is experiment according to the on the constructivist approach, \\
evoked. The problem is presented scientific process skills, we first student's attention is evoked through \\
to the student through games, need to have a problem. A an engagement activity. Such \\
stories, cartoons or questions, and hypothesis is developed for the activities may be a story, cartoon, \\
student's curiosity is evoked. In solution of the problem. Before drawing or a game. The engagement \\
the "explore" step, the problem developing the hypothesis, step should crop a problem or an \\
wondered about by the student is essential background information objective to achieve. The purpose of \\
addressed. For this purpose, an on the problem is explored from conducting the experiment should be \\
available environment setting is different sources. Based on the to solve a problem. If necessary, it \\
constructed for the student. In the findings of the research, a may be attempted to solve the problem \\
"explain" step, student explains hypothesis is created. Variables based on scientific process skills. \\
the outcome of the problem found suiting the hypothesis are While doing the experiment, the \\
by experience. The teacher guides identified. Then, an experiment student should be able to build a link \\
the process where necessary. In suiting the tools and equipment is to the engagement step. Students \\
the "elaborate" step, the student designed. During the experiment, should be questioned during the \\
is asked to associate his/her the following basic processes are experiment and encouraged to \\
learnings with the real world. The employed: $\quad$ observation, participate. Student should be allowed \\
\hline
\end{tabular}




student is urged to think broadly classification, measurement, use to structure, compose, interpret and
through a different point of view. of numbers, regression and develop information. Result of the
In the "evaluate" step, questions prediction. Then, data are formed experiment should be supported with
are asked to the student. into tables/charts for tables/graphs or pictures. After the
Student's understanding is interpretation. The experiment is experiment, students may be
evaluated. Here, what the student finalized. Here, verification of the evaluated through alternative
has learned and his/her actions hypothesis is stated. In the evaluation methods. V diagrams, self-
throughout the process are interpretation part, further assessment forms, performance and
evaluated. The student is also description of the hypothesis is project assignments can be used as
asked to make a self- provided. Meanwhile, different alternative evaluation (PT4).
assessment(PT41). supporting sources may be
provided. And evaluation
questions suiting the experiment
are directed to students (PT9).

Findings on the opinions of pre-service teachers in what positive and negative effects may occur when different experiment methods are applied to secondary school students are presented in Table 5 .

Table 5. Opinions of pre-service teachers in positive and negative aspects of different experiment designs

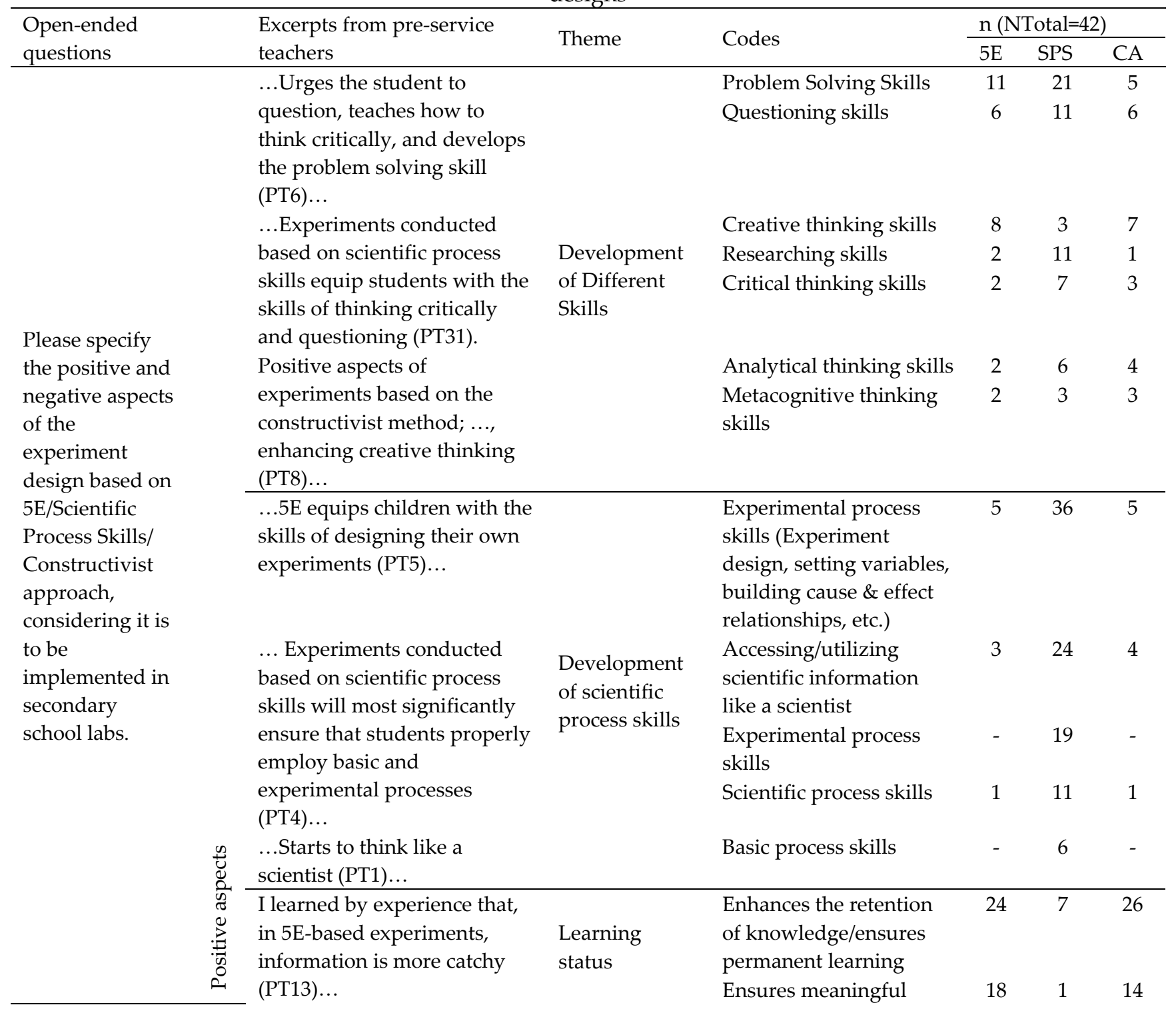


Experiments based on scientific process skills facilitate learning (PT18)...

Constructivist experiment yields meaningful learning (PT38).

...I believe that experiments based on the $5 \mathrm{E}$ method evoke students' attention and do not bother them (PT30).

...In scientific process skills, student can design the experiment with relish without any difficulty (PT39)...

... In experiments based on the constructivist approach, students become active and hence more interested in the topic along with enhanced motivation (PT24)...

...I believe that in a crowded classroom, conducting 5Ebased experiments would be difficult (PT10)...

...As to the negative aspects of experiments conducted based on the constructivist approach, experiments may take long time, leading to time restrictions (PT13). learning

Facilitate learning

The whole learning

$\begin{array}{lll}7 & 5 & 2\end{array}$

progress of the student

is evaluated

Current knowledge is $\quad 1 \quad$ - 5

integrated with new

knowledge

Development

of the affective

domain

Interest in

experiments/arousing

curiosity/gathering focus

Doing experiments with relish

Self-confidence in

designing the

experiment

Motivation in the

experiment

Attitude towards the

experiment

Undertaking a role in the

experiment

$\begin{array}{lll}5 & 1 & 4\end{array}$

$\begin{array}{lll}7 & 1 & 1\end{array}$

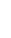

$\begin{array}{lll}3 & 1 & 3\end{array}$

$4 \quad 2$

$\begin{array}{lll}42 & 6 & 12\end{array}$

\begin{tabular}{|c|c|c|c|}
\hline $\begin{array}{l}\text { Application may take } \\
\text { long time }\end{array}$ & 15 & - & 13 \\
\hline $\begin{array}{l}\text { In a crowded classroom, } \\
\text { student participation } \\
\text { may be limited or } \\
\text { difficult to maintain the } \\
\text { classroom discipline }\end{array}$ & 2 & - & 7 \\
\hline $\begin{array}{l}\text { Inadequate teacher } \\
\text { experience may cause } \\
\text { confusion. }\end{array}$ & 7 & - & 1 \\
\hline $\begin{array}{l}\text { There may not be an } \\
\text { ideal method for each } \\
\text { topic. }\end{array}$ & 3 & - & - \\
\hline
\end{tabular}

Pre-service teachers' opinions about the positive aspects of different experiment designs show that, experiments designed based on scientific process skills are more effective in developing problem solving (SPS:21), questioning (SPS:11), researching (SPS:11); critical thinking (SPS:7) and analytical thinking (SPS:6) skills. On the other hand, in scientific process skills, it is observed that primarily the experimental process skills account for the gains (SPS:36,19). While some pre-service teachers addressed experimental process skills partially by mentioning only some steps (e.g. it ensures the formation of the right problem sentence and construction of the right hypothesis) (SPS:36), some made more direct statements such as "it develops experimental process skills" (SPS:19). In ensuring learning and developing some affective fields, experiments based on $5 \mathrm{E}$ and the constructivist approach have more positive aspects mentioned. These approaches were as far as in particular memorability of information (5E:24, CA:26), meaningful learning (5E:18, CA:14) and arousing curiosity/interest/attention in the experiment (5E:42, CA:12) are concerned. In experiments based on $5 \mathrm{E}$, arousing curiosity was stated as a positive aspect by all students involved in the study group.

Pre-service teachers did not state any negative opinion about experiments designed based on scientific process skills, but only one student stated its insufficiency in evoking attention. In experiments designed based on $5 \mathrm{E}$ and the constructivist approach, time restriction is the most emphasized parameter (5E:15, CA:13). Pre-service teachers stated that, instead of conducting each 
experiment based on this method, employing the $5 \mathrm{E}$ and constructivist approach in topics when appropriate would be a solution to overcome the time problem. Other negative aspects addressed by pre-service teachers are crowded classrooms (5E:2, CA:7) and adverse conditions resulting from the teachers' inexperience in implementing the methods (5E:7, CA:1). When stating negative factors, preservice teachers mainly used statements of probability and condition.

Table 6. Excerpts from the opinions of pre-service teachers in positive and negative aspects of different experiment designs

\begin{tabular}{|c|c|c|c|}
\hline & $5 \mathrm{E}$ & SPS & $\mathrm{CA}$ \\
\hline Positive & $\begin{array}{l}\text { In experiments based on the } \\
5 E \text { method, experiment } \\
\text { designing skills of students } \\
\text { are enhanced. With elevated } \\
\text { skills of doing the experiment, } \\
\text { the student's motivation } \\
\text { grows and the student } \\
\text { develops a favourable attitude } \\
\text { towards experiments (PT1). }\end{array}$ & $\begin{array}{l}\text { I believe that it will enhance student's } \\
\text { ability of self-expression, and hence its } \\
\text { self-confidence. Thanks to these } \\
\text { experiments, the student can learn the } \\
\text { concepts of hypothesis, problem and } \\
\text { variable much better. Furthermore, the } \\
\text { skills of decision making, collecting and } \\
\text { interpreting information, and drawing } \\
\text { a conclusion can also be enhanced } \\
\text { through these experiments (PT20). }\end{array}$ & $\begin{array}{l}\text { The student would develop higher } \\
\text { thinking skills as she/he would } \\
\text { enhance questioning skills during } \\
\text { the experiment while trying to } \\
\text { figure out the reason, result and the } \\
\text { fact (PT36). }\end{array}$ \\
\hline Negative & $\begin{array}{l}\text {.. I do not believe that } 5 E \\
\text { necessarily fits exactly in each } \\
\text { experiment. This method may } \\
\text { cause time-related problems } \\
\text { (PT17). }\end{array}$ & $\begin{array}{l}\text {...I believe that it is inadequate as it } \\
\text { does not contain the items of arousing } \\
\text { attention and curiosity (PT5). }\end{array}$ & $\begin{array}{l}\text {...However, it may be difficult to } \\
\text { implement it in a crowded } \\
\text { classroom and deal with each } \\
\text { student individually. Furthermore, } \\
\text { the process may take long time if } \\
\text { the teacher has not done a planned } \\
\text { groundwork (PT35). }\end{array}$ \\
\hline
\end{tabular}

Similarity and difference comparison of experiments designed by pre-service teachers based on $5 \mathrm{~A}$, scientific process skills and the constructivist approach is illustrated in Figure 1. In the figure, codes obtained from the answers of pre-service teachers are stated together with code frequencies indicated in parentheses.

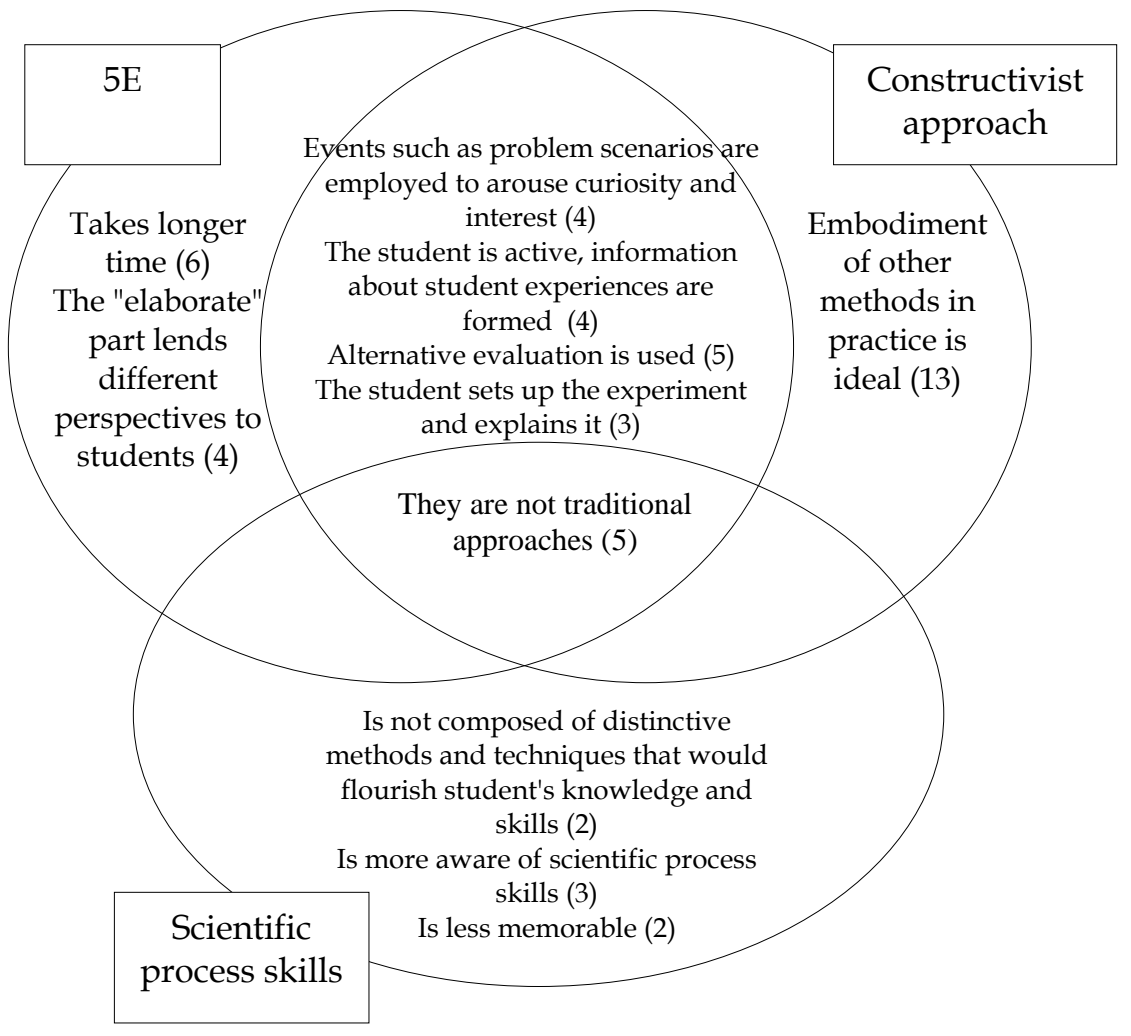

Figure 1. Opinions of pre-service teachers in similarities and differences of experiment designs 
As shown in Figure 1, pre-service teachers most frequently state that experiments designed based on the constructive approach may embody $5 \mathrm{E}$ and scientific process skills (CA:13). In addition, preservice teachers state that it is the 5E-based experiment that takes the longest time (5E:6), yet note the importance of the "elaborate" step in lending different perspectives to students (5E:4). However, for experiments based on scientific process skills, it is underlined that persistence is less compared to the other two experiment designs (SPS:2), the design is not composed of different methods and techniques (SPS:2), and further it is critical for the development of scientific process skills (SPS:3). Preservice teachers state that the unique common point of the three methods is that they are not based on the traditional approach (5E, SPS, CA:5). Pre-service teachers further note experiments based on the $5 \mathrm{E}$ and the constructivist approach are common in that student's curiosity is evoked (5E, CA:4), student is active (5E, CA:4), alternative evaluation is employed (5E, CA:5) and information is structured (5E, CA:3). Excerpts from the responses of pre-service teachers are provided below.

\begin{abstract}
"These 3 methods have many positive aspects compared to the traditional method. 5A is a very good and effective method, but it may pose time restrictions and bring limitations to the topic to be discussed. Scientific process skills may actually furnish students with information on the experiment and science. And the constructivist approach enhances the student's thinking skills." (PST37)

"I believe that the 5E method quires more time and care compared to the constructivist approach. Considering the lengthy presentation and description steps within the method, 5E requires more time. The constructivist approach may actually make up a method incorporating the 5E and scientific process steps. " (PST35)
\end{abstract}

\title{
Conclusion and Discussion
}

While describing the experiments, pre-service teachers note that student is active in all three experiment designs. In addition, teachers indicate that student's activation is higher in experiments based on $5 \mathrm{E}$ and the constructivist approach compared to those based on the experimental scientific process. This may be attributable to stressed student participation in both of these methods. As a matter of fact, student's activation is highlighted in many sources addressing these two methods (Aydoğmuş et al., 2010; Keleş, 2010; Açışlı et al., 2012; Gülbahar et al., 2012; Özmen, 2004; Şahin and Baturay, 2011; Arkün and Aşkar, 2010; Aksoy and Gürbüz, 2013; Hançer, 2006; Turgut and Gürbüz, 2011; Yeşilyurt and Gül, 2011). In addition, the most frequent statement addressed by pre-service teachers is the method of the experiment design. Five constituent steps making up of the 5E learning model (engage, explore, explain, elaborate, evaluate), phases of the scientific process skills (basic and experimental processes: problem, hypothesis, variables, experiment design, table and graphs, result) and three core steps of the constructivist approach (introduction, performance, evaluation) were explained to describe the experiment designs. This may indicate that pre-service teachers pay attention to the methodological properties of each experiment.

Pre-service teachers address some common objectives in the description of all three experiments. These are ensuring learning, problem solving and researching. In experiments based on $5 \mathrm{E}$ and the constructivist approach, objective of ensuring learning was stressed most. In scientific process skills, problem solving and researching are addressed more as an objective. In the literature, initial problem or hypothesis followed by the development of a solution is addressed most for teaching based on scientific problem skills (Aktamıs and Ergin, 2007; Tan and Temiz, 2003; Yıldırım et al., 2013; Kefi et al., 2013; NRC, 2011). The interpretation of this result is that, pre-service teachers highlight predominant properties of the method rather than interpreting that scientific process skills are considered only for problem solving or that other methods do not involve problem solving.

While pre-service teachers' opinions in experiment designs concretely reveal positive aspects as skill development, learning and affective development, they address negative aspects in a more general framework. Pre-service teachers state that all three experiment designs have major contributions to the development of scientific process skills and other various skills, and accommodate myriad of 
influences in developing different skills such as problem solving, questioning, creative thinking and researching. There are studies in the literature addressing positive influence of learning methods based on experiment designs in skill development (Batı and Kaptan, 2013; Yurdakul and Demirel, 2011; Hançer and Yalçın, 2009; Kaya and Karakaya, 2012; Aydın and Yılmaz, 2010; Altun Yalçın et al., 2010). In addition, it is observed that pre-service teachers address experiment designs based on scientific process skills more in the development of these skills. Indeed, scientific process skills may be described as an important method "to develop thinking skills employed for problem solving (Tan and Temiz, 2003)" or "to primarily develop scientific thinking, problem solving and critical thinking skills (Padilla, 2010)".

Pre-service teachers also address the influence of three experiment designs in the development of scientific process skills, with emphasis in major contributions of experiments based on scientific process skills to experimental process skills, using the scientific method, acting like a scientist and basic process skills. Each step of experiments based on scientific process skills is reshaped across experimental and basic process skills. Therefore, it may be argued that pre-service teachers mostly address these gains.

Pre-service teachers indicate positive influences of three experiment designs particularly in the memorability of information and meaningful learning during the realization of learning, however more pre-service teachers address the positive influence of $5 \mathrm{E}$ and the constructivist approach. Similarly, arousing interest and curiosity in students, conducting the experiments with relish, and fostering confidence and motivation are listed as the common positive properties for the three experiment designs in the development of the affective domain, yet with higher frequency in experiment designs based on 5E and the constructivist approach. In his studies, Ilter and Unal (2014) found that, after teaching based on the $5 \mathrm{E}$ method, students' motivation, attitude and sense towards classes were improved and students had more fun accompanied by meaningful learning and higher level of learning persistence. Next, Koç (2002) found that, after the class presented through the constructivist approach, students had more fun in the class, more enthusiastically attended the class accompanied by higher scores of access to high-level learning and higher scores of permanence. In particular, arousing curiosity in student is the most popular gain in experiments design based on the $5 \mathrm{E}$ learning model as addressed by all students. This is believed to be attributable to the fact that the first step of 5E is arousing student's curiosity/attention in the class.

Pre-service teachers address some negative aspects for the 5E and the constructivist approach. These may be listed as lengthy practice, rough application in crowded classrooms and inexperience of teachers. Such negative factors that may be encountered in similar experiment designs are also highlighted in some other studies (Uluçınar et al., 2004; Hofstein and Lunetta, 2004). However, use of condition and probability statements by pre-service teachers in describing negative factors (inexperience of teachers, lack of preliminary groundwork, etc.) may demonstrate that they are aware of the reasons underlying adverse conditions and hence points to take into consideration.

When comparing three experiment designs by similarity and difference, pre-service teachers state that experiments based on the 5E learning model, scientific process skills and the constructivist approach commonly differ from the traditional approach. In particular, pre-service teachers state that experiments based on $5 \mathrm{E}$ and the constructivist approach commonly arouse curiosity in students, employ alternative evaluation methods and provide the student with a more active role. The $5 \mathrm{E}$ learning model is an application modality of the constructive approach (Özmen, 2004; Aksoy and Gürbüz, 2013; Aktaş, 2013; Jobrack, 2013), and have many common points in this respect. In addition, they also bear differences as they contain various steps. As a matter of fact, while noting that $5 \mathrm{E}$ is more lengthy and lends different perspectives to students as the method's distinctions, pre-service teachers further indicate that the constructivist approach may embody both $5 \mathrm{E}$ and scientific process skills. It is further highlighted that, combined use of these methods (e.g. by regularly implementing the scientific method steps in experiments based on the constructive approach) may yield a laboratory environment where gains are further flourished.

The following proposals were developed based on the results of the study: 
Each experiment has similar and different gains. Using appropriate experiment for different topics rather than conventionally employing the same for each topic, and identifying the right method in the experiment in line with predefined objectives would yield more concrete gains in students. In subsequent studies, particularly through experiments tailored to the topic and to predefined skills aimed for students, use of the appropriate method by teachers/pre-service teachers for the specific topic may be evaluated or teachers/pre-service teachers may be directed towards using the appropriate method.

Utilizing distinctive methods and techniques as much as possible in experiments will prevent monotonous progress of the class. For this reason, teachers should importantly get familiar with and experience different methods and techniques. However, while performing these actions, the purpose, subject and proposed gain should be maintained.

Teachers should have the capability of designing experiment in line with their current level and background. Therefore, they should properly observe and assess their students. And this may be guaranteed by means of employing right tools of evaluation before, during and after the learning process. From this point of view, pre-service teachers should have a good knowledge of alternative evaluation methods.

For pre-service teachers, laboratory should not be a typical area merely reserved for doing experiments, but a facility where alternative methods of doing experiments are demonstrated to preservice teachers, and all of their skills or incompetences are identified by themselves or assessed by the instructor in favour of further experience.

\section{References}

Açışlı, S., Turgut, Ü. and Gürbüz, F. (2012). Elektrik konularının öğretiminde 5E modelinin öğrenci başarısına etkisi. Eğitim ve Öğretim Araştırmaları Dergisi, 1(3), 345-350.

Aksoy, G. and Gürbüz, F. (2013). 5E Modeli'nin öğrencilerin akademik başarısına etkisi: “Kuvvet ve Hareket" ünitesi örneği. İnönü Üniversitesi Eğitim Fakültesi Dergisi, 14 (2), 1-16.

Aktamış, H. and Ergin, Ö. (2007). Bilimsel süreç becerileri ile bilimsel yaratıclık arasındaki ilişkinin belirlenmesi. Hacettepe Üniversitesi Eğitim Fakültesi Dergisi (H. U. Journal of Education), 33, 11-23.

Aktamış, H. and Ergin, Ö. (2008). The effect of scientific process skills education on students' scientific creativity, science attitudes and academic achievements. Asia-Pacific Forum on Science Learning and Teaching, 9(1), 1-21.

Aktaş, M. (2013). 5E öğrenme modeli ve işbirlikli öğrenmenin biyoloji tutumuna etkisinin cinsiyet bakımından değerlendirilmesi. Ondokuz Mayıs Üniversitesi Eğitim Fakültesi Dergisi, 32(2), 1-19.

Altun Yalçın, S., Açışlı, S. and Turgut, Ü. (2010). 5E öğretim modelinin fen bilgisi öğretmen adaylarının bilimsel işlem becerilerine ve fizik laboratuarlarına karşı tutumlarına etkisi. Kastamonu Eğitim Dergisi, 18(1), 147-158.

Arı, E. and Bayram, H. (2011). Yapılandırmacı yaklaşım ve öğrenme stillerinin laboratuvar uygulamalarında başarı ve bilimsel süreç becerileri üzerine etkisi. İlköğretim Online, 10(1), 311-324. http://ilkogretim-online.org.tr (accessed December 2013)

Arkün, S. and Aşkar, P. (2010). Yapılandırmacı öğrenme ortamlarını değerlendirme ölçeğinin geliştirilmesi. Hacettepe Üniversitesi Eğitim Fakültesi Dergisi (H. U. Journal of Education), 39, 32-43.

Aydın, N. and Yılmaz, A. (2010). Yapılandırıcı yaklaşımın öğrencilerin üst düzey bilişsel becerilerine etkisi. Hacettepe Üniversitesi Eğitim Fakültesi Dergisi (H. U. Journal of Education), 39, 57-68.

Aydoğdu, B. and Ergin, Ö. (2008). Fen ve teknoloji dersinde kullanılan farklı deney tekniklerinin öğrencilerin bilimsel süreç becerilerine etkileri. Ege Eğitim Dergisi, 9(2), 15-36.

Aydoğdu, B., and Ergin, Ö. (2010). Fen ve teknoloji dersinde kullanılan farklı deney tekniklerinin öğrencilerin öğrenme yaklaşımlarına etkileri. International Conference on New Trends in Education and Their Implications (ICONTE), 11-13 December 2010, Antalya-Türkiye.

Aydoğmuş, E., Sarıkoç, A. and Cerit Berber, N. (2010). Lise 2 fizik dersi iş-enerji konusunun öğretiminde 5E modelinin öğrenci başarısına ve tutuma etkisinin araştıılması. Selçuk Üniversitesi Ahmet Keleşoğlu Eğitim Fakültesi Dergisi, 29, 83-94.

Bates, G.C. (1978). The role of the laboratory in secondary school science programs. Ed. Mary Budd Rowe, What research says to the science teacher. Eric number: ED148628, 55-82.

Batı, K. and Kaptan, F. (2013). The effects of science education based on science process skills on scientific problem solving. İlköğretim Online, 12(2), 512-527, [Online]: http:/ /ilkogretim-online.org.tr (accessed April 2013)

Bell, P. (2004) The school science laboratory: Considerations of learning, technology, and scientific practice. National Academy of Sciences, High School Science Laboratories: Role and Vision. http://www7.nationalacademies.org/bose/philip_bell_\%20final_\%20paper.pdf (accessed January 2013)

Berg, E. (2009). The PCK of teaching in the laboratory: Turning manipulation of equipment into manipulation of ideas. In: O. de Jong and L. Halim (eds): Teachers' Professional Knowledge in Science and Mathematics Education: Views from Malaysia and Abroad. Publisher: Faculty of Education, Universiti Kebangsaan Malaysia, p85-110. http://www.iederkindeentalent.nl/wp-content/uploads/2012/06/The-PCK.pdf (accessed January 2013) 
Bhukuvhani, C., Kusure, L., Munodawafa, V., Sana, A., and Gwizangwe, I. (2010). Pre-service Teachers' use of improvised and virtual laboratory experimentation in Science teaching. International Journal of Education and Development using Information and Communication Technology (IJEDICT), 6(4), 27-38.

Bilen, K. and Aydoğdu, M. (2010). Bitkilerde fotosentez ve solunum kavramlarının öğretiminde TGA (tahmin et-gözle-açıkla) stratejisinin kullanım. Mustafa Kemal Üniversitesi Sosyal Bilimler Enstitüsü Dergisi, 7(14), 179-194.

Bilen, K. (2009). “Tahmin et-gözle-açıkla” yöntemine dayalı laboratuvar uygulamalarının öğretmen adaylarının kavramsal başarılarına, bilimsel süreç becerilerine, tutumlarına ve bilimin doğası hakkındaki görüşlerine etkisi. Gazi University, Institute of Educational Sciences, Unpublished disertation, Ankara.

Bilen, K., and Aydoğdu, M. (2012). Tahmin Et-Gözle-Açıkla (TGA) stratejisine dayalı laboratuar uygulamalarının öğrencilerin bilimsel süreç becerileri ve bilimin doğası hakkındaki düşünceleri üzerine etkisi. Gaziantep Üniversitesi Sosyal Bilimler Dergisi, 11 (1), 49-69.

Bilen, K., and Köse, S. (2012). Yapılandırmacı öğrenme teorisine dayalı etkili bir strateji: Tahmin-gözlem-açıklama (TGA) "Bitkilerde Büyüme ve Gelişme". Pamukkale Üniversitesi Eğitim Fakültesi Dergisi, 31, 123-136.

Bilen, K., Köse, S., and Uşak, U. (2011). Tahmin et-Gözle-Açıla (TGA) stratejisine dayalı laboratuar uygulamalarının fen bilgisi öğretmen adaylarının osmoz ve difüzyon konusunu anlamalarına etkisi. Pamukkale Üniversitesi Sosyal Bilimler Enstitüsü Dergisi, 9, 115-127.

Bozkurt, E., and Sarıkoç, A. (2008). Fizik eğitiminde sanal laboratuar, geleneksel laboratuarın yerini tutabilir mi?. Selçuk Üniversitesi Ahmet Keleşoğlu Eğitim Fakültesi Dergisi, 25, 89-100.

Coştu, S. (2009). Matematik öğretiminde bağlamsal öğrenme ve öğretme yaklaşımına göre tasarlanan öğrenme ortamlarında ögretmen deneyimleri. Karadeniz Teknik University, Institute of Educational Sciences, Unpublished master thesis, Trabzon.

Creswell, J.W. (2008). Educational research: Planning, conducting, and evaluating quantitative and qualitative research (3rd edition). New Jersey: Pearson International Education.

Çakal, S. (2012). İlköğretim ikinci kademe, fen ve teknoloji öğretiminde bilimsel süreç becerilerine dayalı ev laboratuarı uygulamaları ve madde konusu ile ilgili örnek etkinlikler. Kastamonu University, Institute of Sciences, Unpublished master thesis, Kastamonu.

Çepni, S., Ayas, A., Johnson, D., and Turgut, F. (1997). Fizik Öğretimi. YÖK/Dünya Bankası, Milli Eğitimi Geliştirme Projesi, Hizmet Öncesi Öğretmen Eğitimi, Ankara.

Çetin, O., and Günay, Y. (2011). Fen eğitimine yönelik örnek bir web tabanlı öğretim materyalinin hazırlanması ve bu materyalin öğretmen öğrenci görüşleri doğrultusunda değerlendirilmesi. Ahi Evran Üniversitesi Eğitim Fakültesi Dergisi, 12 (2), 175-202.

Dahar, M.A., and Faize, F.A. (2011). Effect of the availability and the use of science laboratories on academic achievement of students in Punjab (Pakistan). European Journal of Scientific Research, 51(2), 193-202.

Demircioğlu, H., Vural, S., and Demircioğlu, G. (2012). “REACT” stratejisine uygun hazırlanan materyalin üstün yetenekli öğrencilerin başarısı üzerine etkisi. Ondokuz Mayıs Üniversitesi Eğitim Fakültesi Dergisi, 31 (2), 101-144.

Domin, D.S. (2007). Students' perceptions of when conceptual development occurs during laboratory instruction. Chemistry Education Research and Practice, 8(2), 140-152.

Erdoğdu, S. (2011). Elektrik konularının 5E modeline göre öğretiminin öğrencilerin akademik başarılarına ve tutumlarına etkisi. Selçuk Üniversitesi, Institute of Educational Sciences, Unpublished master thesis, Konya.

Gülbahar, Y., Avcı, Ü. and Ergün, E. (2012). Yaparak öğrenme: “Hedefe dayalı senaryo yaklaşımı” uygulamasına bir örnek. Eğitim ve Bilim, 37(165), 293-306.

Hançer, A.H. and Yalçın, N. (2009). Fen eğitiminde yapılandırmacı yaklaşıma dayalı bilgisayar destekli öğrenmenin problem çözme becerisine etkisi. GÜ, Gazi Eğitim Fakültesi Dergisi, 29(1), 55-72.

Hançer, A.H. (2006). Yapılandırmacı fen eğitimi yaklaşımının öğrencilerin öğrenmelerini geliştirmesi. International Journal of Environmental and Science Education (IJESE), 1(2), 181-188.

Hofstein, A. (2004). The laboratory in chemistry education: Thirty years of experience with developments, implementation, and research. Chemistry Education Research and Practice, 5(3), 247-264.

Hofstein, A., and Lunetta, V.N. (2004). The Laboratory in Science Education: Foundations for the Twenty-First Century. Science Education, 88(1), 28-54.

Huppert, F. and Lazarowitz, R. (2002). Computer simulations in the high school: students' cognitive stages, science process skills and academic achievement in microbiology. International Journal of Science Education, 24(8), 803-821.

İlter, İ. and Ünal, Ç. (2014). Sosyal bilgiler öğretiminde 5e öğrenme döngüsü modeline dayalı etkinliklerin öğrenme sürecine etkisi: bir eylem araştırması. Türkiye Sosyal Araştırmalar Dergisi (TSA), 181, 295-330.

Jobrack, B. (2013). The 5E instructional model: Engage explore explain evaluate extend. [Online]: Retrieved on 29-October-2013, at URL: https:/ / www.mheonline.com/secondaryscience/pdf/5e_lesson_cycle.pdf (accessed December 2013)

Karatekin, P., and Öztürk, M. (2012). Fen ve teknoloji öğretmen adaylarının genel biyoloji laboratuarında TGA tekniğiyle işlenmiş "hücre ve dokular" ünitesinin öğrencilerin başarı ve bilimsel süreç becerileri üzerine etkisi. Celal Bayar Üniversitesi Eğitim Fakültesi Dergisi, 2 (2), 111-137.

Kaya, H.İ and Karakaya, Ş. (2012). Öğretmen eğitiminde yapılandırmacı öğrenmeye dayalı uygulamaların öğretmen adaylarının problem çözme eğilimlerine etkileri. Sosyal Bilimler Enstitüsü Dergisi, 9, 79-95.

Kefi, S., Çeliköz, N. and Erişen, Y. (2013). Okulöncesi eğitim öğretmenlerinin temel bilimsel süreç becerilerini kullanım düzeyleri. Eğitim ve Öğretim Araştırmaları Dergisi, 2(2), 300-319.

Keleş, Y. (2010). Fen eğitiminde öğrenme döngüsü modelleri. Mersin Üniversitesi Eğitim Fakültesi Dergisi, 6(1), 41-51.

Kocakülah, A., and Savaş, E. (2011). Fen bilgisi öğretmen adaylarının deney tasarlama ve uygulama sürecine ilişkin görüşleri. Ondokuz Mayıs Üniversitesi Eğitim Fakültesi Dergisi, 30(1), 1-28.

Koç, G. (2002). Yapılandırmacı öğrenme yaklaşımının duyuşsal ve bilişsel öğrenme ürünlerine etkisi. Hacettepe University, Institute of Social Sciences, Unpublished disertation, Ankara.

Küçük, Z. (2011). Zenginleştirilmiş 5E modelinin 7.sınıf öğrencilerinin kavramsal değişimine etkisi: Elektrik akımı örneği. Karadeniz Teknik University, Institute of Educational Sciences, Unpublished master thesis, Trabzon. 
Marbach-Ad, G., and Claassen, L.A. (2001). Improving students' questions in inquiry labs. The American Biology Teacher, 63(6), 410-419.

Mc Donnell, C., O'connor, C., and Seery M.K. (2007). Developing practical chemistry skills by means of student-driven problem based learning mini-projects. Chemistry Education Research and Practice, 8(2), 130-139.

Ministry of Education (Milli Eğitim Bakanlığ1 [MEB]) (2006). İlköğretim fen ve teknoloji dersi (6,7,8. sınıflar için) öğretim program. Ankara: MEB publishing.

NRC (National Research Counc1). (2000). Inquiry and the National Science Education Standards: A Guide for Teaching and Learning. National Academy Press: Washington, D.C.

NRC (National Research Counc1). (2011). A Framework for K-12 Science Education. National Academy of Sciences. National Academy Press: Washington, D.C.

Özdemir, H. (2011). “Tahmin et-gözle-açıkla” stratejisine dayalı laboratuar uygulamalarının fen bilgisi öğretmen adaylarının asitler - bazlar konusunu anlamalarına etkisi. Pamukkale Üniversitesi, Institute of Sciences, Unpublished master thesis, Denizli.

Özmen, H. (2004). Fen öğretiminde öğrenme teorileri ve teknoloji destekli yapılandırmacı (constructivist) öğrenme. The Turkish Online Journal of Educational Technology (TOJET), 3(1), 100-111.

Padilla, M. (2010). Inquiry, process skills, and thinking in science. Science Scope, 19(2), 8-9.

Patro, E.T. (2008). Teaching Aerobic Cell Respiration Using the 5Es. American Biology Teacher, 70(2), p85-87.

Sevinç, E. (2008). 5E öğretim modelinin organik kimya laboratuvarı dersinde uygulanmasının öğrencilerin kavramsal anlamalarına, bilimsel süreç becerilerinin gelişimine ve organik kimya laboratuvarı dersine karşı tutumlarına etkisi. Gazi Üniversitesi, Institute of Educational Sciences, Unpublished master thesis, Ankara.

Şahin, S. (2006). Computer simulations in science education: Implications for distance education. Turkish Online Journal of Distance Education (TOJDE), 7 (4), 132-146.

Şahin, Ş. and Baturay, M.H. (2011). Ortaöğretim öğrencilerinin 5E öğrenme modeli ile desteklenmiş webqust ortamına ilişkin görüşlerinin değerlendirilmesi. 5th International Computer \& Instructional Technologies Symposium, 22-24 September, Firat University, Elazı $\breve{g}$.

Tan, M. and Temiz, B.K. (2003). Fen öğretiminde bilimsel süreç becerilerinin yeri ve önemi. Pamukkale Üniversitesi Eğitim Fakültesi Dergisi, 13, 89-101.

Turgut, Ü. and Gürbüz, F. (2011). Isı ve sıcaklık konusunda 5E modeliyle öğretimin öğrencilerdeki kavramsal değişime ve onların tutumlarına etkisi. International Online Journal of Educational Sciences (IOJES), 3(2), 679-706.

Tümay, H. (2001). Üniversite genel kimya laboratuvarlarında öğrencilerin kavramsal değişimi, başarısı, tutumu ve algılamaları üzerine yapılandırıcı öğretim yönteminin etkileri. Gazi Üniversitesi, Institute of Educational Sciences, Unpublished master thesis, Ankara.

Tüysüz, C. (2010). The effect of the virtual laboratory on students' achievement and attitude in chemistry. International Online Journal of Educational Sciences, 2 (1), 37-53.

Uluçınar, Ş., Cansaran, A., and Karaca, A. (2004) Fen bilimleri laboratuar uygulamalarının değerlendirilmesi. Türk Eğitim Bilimleri Dergisi, 2(4), 465-475.

Ültay, N., and Çalık, M. (2011). Asitler ve bazlar konusu ile ilgili örnekler üzerinden 5E modelini ve REACT stratejisini ayırt etmek. Necatibey Eğitim Fakültesi Elektronik Fen ve Matematik Eğitimi Dergisi (EFMED), 5(2), 199-220.

Yeşilyurt, M., Bayraktar, Ş. and Erdemir, N. (2004). Laboratuvarda Bütünleştiricilik: R-S Modeli. Türk Fen Eğitimi Dergisi (TÜFED), 1(1), 59-70.

Yeşilyurt, S. and Gül, Ş. (2011). Yapılandırmacı öğrenme yaklaşımına dayalı hazırlanan çalışma yaprağının öğrenci başarısına etkisi (Pilot Uygulama). Uludağ Üniversitesi Eğitim Fakültesi Dergisi, 24(1), 247-261.

Yeung, A., Pyke, S.M., Sharma,M.D., Barrie, S.C., Buntine, M.A., Da Silva, K.B., Kable, S.H., and Lim, K.F. (2011). The advancing science by enhancing learning in the laboratory (ASELL) Project: The first Australian multidisciplinary workshop. International Journal of Innovation in Science and Mathematics Education, 19(2), 51-72.

Yıldırım, M., Atila, M.E., Özmen, H. and Sözbilir, M. (2013). Fen bilimleri öğretmen adaylarının bilimsel süreç becerilerinin geliştirilmesi hakkındaki görüşleri. Mersin Üniversitesi Eğitim Fakültesi Dergisi, 9(3), 27-40.

Yıldız, E., Akpınar, E., Aydoğdu, B., and Ergin, Ö. (2006). Fen bilgisi öğretmenlerinin fen deneylerinin amaçlarına yönelik tutumları. Türk Fen Eğitimi Dergisi (TÜFED), 3(2), 2-18.

Yıldız, E., Aydoğdu, B., Akpınar, E., and Ergin, Ö. (2010). Fen bilgisi ögretmenlerinin fen deneylerine yönelik tutumları. Boğaziçi Üniversitesi Eğitim Dergisi, 24(2), 71-86.

Yurdakul, B. and Demirel, Ö. (2011). Yapılandırmacı öğrenme yaklaşımının öğrenenlerin üstbiliş farkındalıklarına katkısı. Uluslararası Eğitim Programları ve Öğretim Çalışmaları Dergisi, 1(1), 71-85.

Zoller, U., and Pushkin, D. (2007). Matching Higher-Order Cognitive Skills (HOCS) promotion goals with problem-based laboratory practice in a freshman organic chemistry course. Chemistry Education Research and Practice, 8(2), 153-171. 